\title{
Effects of Cadmium Stress on Photosynthetic Characteristics of Grape Seedlings
}

\author{
Lijin Lin ${ }^{1, b}$, Lei Yuan ${ }^{2, b}$, Li Wang ${ }^{3, c}$, and Ming'an Liao ${ }^{2, d^{*}}$ \\ ${ }^{1}$ Institute of Pomology and Olericulture, Sichuan Agricultural University, Chengdu, China \\ ${ }^{2}$ College of Horticulture, Sichuan Agricultural University, Chengdu, China \\ ${ }^{3}$ College of Animal Science and Technology, Sichuan Agricultural University, Chengdu, China \\ allj800924@163.com, b605862190@qq.com, cwangli19800327@163.com, dIman@sicau.edu.cn \\ *Corresponding author, Lijin Lin, Lei Yuan and Li Wang contributed equally to this work.
}

Keywords: Cadmium stress; Photosynthetic characteristics; Grape seedlings

Abstract: The effects of cadmium (Cd) stress on photosynthetic characteristics of grape seedlings were investigated through a pot experiment. The results showed that with the increase of $\mathrm{Cd}$ concentrations, the photosynthetic pigment content and net photosynthetic rate decreased. The transpiration rate, $\mathrm{CO}_{2}$ concentration of intercellular and stomatal conductance increased under $\mathrm{Cd}$ stress compared with the control, but water use efficiency decreased. With the increase of $\mathrm{Cd}$ concentrations, the vapor pressure deficit of leaf had the trend of increasing when the dose of Cd was not more than $10 \mathrm{mg} / \mathrm{kg}$, and decreased when the dose of Cd was higher than $10 \mathrm{mg} / \mathrm{kg}$. Therefore, $\mathrm{Cd}$ treatment could inhibit the photosynthesis of grape seedlings.

\section{Introduction}

With the development of industrial and agricultural production, the heavy metal contaminated soil area increases [1-2]. According to the reports, China's cadmium (Cd) contaminated soil area has reached 200,000 $\mathrm{km}^{2}$, accounting for the total area of arable land 1/6 [3]. In orchard, the research shows that the heavy metal pollution is also more serious, especially the pollution of $\mathrm{Cd}$ has been seriously in some areas, the Cd content in fruit of fruit trees has exceeded the standard [4-5].

Grape is one of the world's most important fruit tree species, the fruit of grape is rich in a variety of carbohydrate, antioxidant, anti-aging and anti-cancer substances, etc., with a high nutritional value and health care function, much consumers love [6-7]. China's fresh grape planting area is the second of world for five consecutive years [8-9]. In recent years, the industrial "three wastes" emissions, urban sewage and garbage pollution and containing heavy metals, pesticides, fertilizers and organic fertilizer unreasonable application result the heavy metal pollution in farmland, especially $\mathrm{Cd}$ pollution has seriously exceeded [10-11]. So, study the eco-physiology of grape under Cd stress is very important. The aim of this study was to study the effects of $\mathrm{Cd}$ stress on photosynthetic characteristics of grape seedlings, and provided a reference for grape production in Cd-contaminated soil areas.

\section{Materials and Methods}

Materials. The soil samples used in the experiment were collected from the Chengdu campus of Sichuan Agricultural University $\left(30^{\circ} 42^{\prime} \mathrm{N}, 103^{\circ} 51^{\prime} \mathrm{E}\right)$ in May 2016 , which were uncontaminated by heavy metals. The grape seedlings were 'Jufeng' and 'Xiahei', which were the annual cutting seedlings with $25 \mathrm{~cm}$ height of young sprout.

Experimental Design. The soil samples were air-dried and passed through a 5-mm sieve. Four kilograms of the air-dried soil was weighed into each polyethylene pot $(18 \mathrm{~cm}$ high, $21 \mathrm{~cm}$ in diameter). Cd was added to soils as $\mathrm{CdCl}_{2} \cdot 2.5 \mathrm{H}_{2} \mathrm{O}$ at $0,1,5,10,15$ and $20 \mathrm{mg} / \mathrm{kg}$ in April 2016, and the soil moisture was maintained at $80 \%$ of field capacity for one month. The uniform grape seedlings were transplanted into each pot in May 2016, and watered every day to keep the soil moisture content maintaining at $80 \%$ of field capacity. One pot planted one seedling, and each treatment was 6 
replicates, respectively. After grape seedlings grew two months (July 2016), the upper mature leaves of grape seedlings were collected to determine the photosynthesis and the photosynthetic pigment (chlorophyll $a$, chlorophyll $b$ and total chlorophyll) content [12]. The photosynthesis of each plant was determined by using LI-6400 portable photosynthesis meter (LI-COR Inc., USA). The photosynthetic parameters of the photosynthesis meter were manual control $\mathrm{CO}_{2}$ concentration 400 $\mu \mathrm{mol} \cdot \mathrm{CO}_{2} / \mathrm{mol}$, temperature $30^{\circ} \mathrm{C}$, light intensity $1500 \mu \mathrm{mol} / \mathrm{m}^{2} \cdot \mathrm{s}$. The determination of photosynthetic parameters were net photosynthetic rate $(\mathrm{Pn})$, transpiration rate $(\mathrm{Tr})$, stomatal conductance $(\mathrm{Gs}), \mathrm{CO}_{2}$ concentration of intercellular $(\mathrm{Ci})$ and vapor pressure deficit of leaf $(\mathrm{VpdL})$, and each plant was repeated three times.

Statistical Analyses. Statistical analyses were conducted using SPSS 13.0 statistical software (IBM, Chicago, IL, USA). Data were analyzed by one-way analysis of variance with least significant difference (LSD) at the $\mathrm{p}=0.05$ confidence level. Water use efficiency (WUE) $=$ net photosynthetic rate $(\mathrm{Pn}) /$ transpiration rate $(\mathrm{Tr})[13]$.

\section{Results and Discussion}

Photosynthetic Pigment Content. With the increase of $\mathrm{Cd}$ concentrations, the contents of chlorophyll $a$, chlorophyll $b$ and total chlorophyll of grape seedlings decreased (Table 1). At 1, 5, 10, 15 and $20 \mathrm{mg} / \mathrm{kg} \mathrm{Cd}$ treatments, the total chlorophyll content of 'Jufeng' seedlings decreased by $3.97 \%(p>0.05), 10.89 \%(p<0.05), 31.59 \%(p<0.05), 32.39 \%(p<0.05)$ and $50.65 \%(p<0.05)$, respectively, compared with the control, and the total chlorophyll content of 'Xiahei' seedlings decreased by $3.20 \%(p>0.05), 5.54 \%(p<0.05), 8.55 \%(p<0.05), 15.72 \%(p<0.05)$ and $16.63 \%(p$ $<0.05)$, respectively, compared with the control. So, Cd stress inhibited the growth of grape seedlings.

Table 1 Effects of Cd stress on photosynthetic pigment content of grape seedlings

\begin{tabular}{|c|c|c|c|}
\hline Treatments & $\begin{array}{c}\text { Chlorophyll } a \\
(\mathrm{mg} / \mathrm{g})\end{array}$ & $\begin{array}{c}\text { Chlorophyll } b \\
(\mathrm{mg} / \mathrm{g})\end{array}$ & $\begin{array}{c}\text { Total chlorophyll } \\
(\mathrm{mg} / \mathrm{g})\end{array}$ \\
\hline Jufeng & & & \\
\hline 0 & $1.402 \pm 0.024 \mathrm{a}$ & $0.361 \pm 0.010 \mathrm{a}$ & $1.763 \pm 0.035 \mathrm{a}$ \\
\hline 1 & $1.373 \pm 0.098 \mathrm{ab}$ & $0.320 \pm 0.031 \mathrm{~b}$ & $1.693 \pm 0.129 \mathrm{ab}$ \\
\hline 5 & $1.264 \pm 0.061 \mathrm{~b}$ & $0.307 \pm 0.006 \mathrm{~b}$ & $1.571 \pm 0.067 \mathrm{~b}$ \\
\hline 10 & $0.959 \pm 0.022 \mathrm{c}$ & $0.247 \pm 0.010 \mathrm{c}$ & $1.206 \pm 0.033 \mathrm{c}$ \\
\hline 15 & $0.949 \pm 0.029 \mathrm{c}$ & $0.243 \pm 0.001 \mathrm{c}$ & $1.192 \pm 0.030 \mathrm{c}$ \\
\hline 20 & $0.698 \pm 0.034 \mathrm{~d}$ & $0.172 \pm 0.005 \mathrm{~d}$ & $0.870 \pm 0.038 \mathrm{~d}$ \\
\hline Xiahei & & & \\
\hline 0 & $1.220 \pm 0.023 \mathrm{a}$ & $0.313 \pm 0.005 \mathrm{a}$ & $1.533 \pm 0.028 \mathrm{a}$ \\
\hline 1 & $1.177 \pm 0.014 \mathrm{~b}$ & $0.307 \pm 0.018 \mathrm{a}$ & $1.484 \pm 0.004 \mathrm{ab}$ \\
\hline 5 & $1.149 \pm 0.017 \mathrm{bc}$ & $0.299 \pm 0.007 \mathrm{a}$ & $1.448 \pm 0.023 \mathrm{bc}$ \\
\hline 10 & $1.117 \pm 0.014 \mathrm{c}$ & $0.285 \pm 0.006 \mathrm{ab}$ & $1.402 \pm 0.020 \mathrm{c}$ \\
\hline 15 & $1.042 \pm 0.004 \mathrm{~d}$ & $0.250 \pm 0.022 \mathrm{bc}$ & $1.292 \pm 0.025 \mathrm{~d}$ \\
\hline 20 & $1.032 \pm 0.018 \mathrm{~d}$ & $0.246 \pm 0.020 \mathrm{c}$ & $1.278 \pm 0.038 \mathrm{~d}$ \\
\hline
\end{tabular}

Net Photosynthetic Rate (Pn). With the increase of Cd concentrations, the Pn of grape seedlings decreased (Table 1). At 1, 5, 10, 15 and $20 \mathrm{mg} / \mathrm{kg}$ Cd treatments, the Pn of 'Jufeng' seedlings decreased by $11.07 \%(p<0.05), 11.33 \%(p<0.05), 11.67 \%(p<0.05), 26.24 \%(p<0.05)$ and $37.90 \%(p<0.05)$, respectively, compared with the control, and the Pn of 'Xiahei' seedlings decreased by $7.67 \%(p>0.05), 9.25 \%(p<0.05), 14.25 \%(p<0.05), 21.83 \%(p<0.05)$ and $29.17 \%$ $(p<0.05)$, respectively, compared with the control. So, Cd stress inhibited the Pn of grape seedlings. Transpiration Rate (Tr). The Tr of grape seedlings increased under Cd stress compared with the control (Table 2). With the increase of Cd concentrations from 1 to $20 \mathrm{mg} / \mathrm{kg}$, the $\mathrm{Tr}$ of grape seedlings had the trend of decreasing. Compared with the control, the Tr differences of 'Jufeng' 
seedlings under 1 and $5 \mathrm{mg} / \mathrm{kg} \mathrm{Cd}$ treatments were significant, the other concentrations of Cd were not significant. For 'Xiahei' seedlings, all treatments of the Tr differences were not significant.

Water Use Efficiency (WUE). The WUE of grape seedlings decreased under Cd stress compared with the control (Table 2). With the increase of Cd concentrations from 1 to $20 \mathrm{mg} / \mathrm{kg}$, the WUE of grape seedlings had the trend of increasing when the dose of Cd was not more than $10 \mathrm{mg} / \mathrm{kg}$, and decreased when the dose of Cd was higher than $10 \mathrm{mg} / \mathrm{kg}$.

Table 2 Effects of $\mathrm{Cd}$ stress on net photosynthetic rate and transpiration rate of grape seedlings

\begin{tabular}{|c|c|c|c|}
\hline Treatments & $\begin{array}{c}\mathrm{Pn} \\
\left(\mu \mathrm{mol} \cdot \mathrm{CO}_{2} / \mathrm{m}^{2} \cdot \mathrm{s}\right)\end{array}$ & $\left.\begin{array}{c}\mathrm{Tr} \\
(\mathrm{mmol} \mathrm{H}\end{array} \mathrm{H}^{2} / \mathrm{m}^{2} \cdot \mathrm{s}\right)$ & $\begin{array}{c}\text { WUE } \\
\left(\mu \mathrm{mol} \cdot \mathrm{CO}_{2} / \mathrm{mmol} \mathrm{H}_{2} \mathrm{O}\right)\end{array}$ \\
\hline Jufeng & $11.74 \pm 0.70 \mathrm{a}$ & $3.71 \pm 0.58 \mathrm{~b}$ & $3.16 \pm 0.58 \mathrm{a}$ \\
\hline 0 & $10.44 \pm 0.17 \mathrm{~b}$ & $4.94 \pm 0.36 \mathrm{a}$ & $2.11 \pm 0.12 \mathrm{~b}$ \\
\hline 1 & $10.41 \pm 0.46 \mathrm{~b}$ & $4.79 \pm 0.35 \mathrm{a}$ & $2.17 \pm 0.20 \mathrm{~b}$ \\
\hline 5 & $10.37 \pm 0.21 \mathrm{~b}$ & $4.53 \pm 0.23 \mathrm{ab}$ & $2.29 \pm 0.07 \mathrm{~b}$ \\
\hline 10 & $8.66 \pm 0.66 \mathrm{c}$ & $4.12 \pm 0.85 \mathrm{ab}$ & $2.10 \pm 0.59 \mathrm{~b}$ \\
\hline 15 & $7.29 \pm 0.07 \mathrm{~d}$ & $4.11 \pm 0.66 \mathrm{ab}$ & $1.77 \pm 0.25 \mathrm{~b}$ \\
\hline 20 & & & $3.95 \pm 0.78 \mathrm{a}$ \\
\hline Xiahei & $12.00 \pm 0.87 \mathrm{a}$ & $3.04 \pm 0.47 \mathrm{a}$ & $3.08 \pm 0.83 \mathrm{ab}$ \\
\hline 0 & $11.08 \pm 0.62 \mathrm{ab}$ & $3.60 \pm 0.94 \mathrm{a}$ & $3.11 \pm 0.29 \mathrm{ab}$ \\
\hline 1 & $10.89 \pm 0.61 \mathrm{~b}$ & $3.50 \pm 0.20 \mathrm{a}$ & $3.13 \pm 0.20 \mathrm{ab}$ \\
\hline 5 & $10.29 \pm 0.31 \mathrm{bc}$ & $3.29 \pm 0.14 \mathrm{a}$ & $2.90 \pm 0.24 \mathrm{~b}$ \\
\hline 10 & $9.38 \pm 0.49 \mathrm{~cd}$ & $3.23 \pm 0.41 \mathrm{a}$ & $2.72 \pm 0.46 \mathrm{~b}$ \\
\hline 15 & $8.50 \pm 0.34 \mathrm{~d}$ & $3.13 \pm 0.44 \mathrm{a}$ & \\
\hline 20 & \multicolumn{3}{|c}{} \\
\hline
\end{tabular}

$\mathrm{CO}_{2}$ Concentration of Intercellular (Ci). The same as the Tr, The $\mathrm{Ci}$ of grape seedlings increased under $\mathrm{Cd}$ stress compared with the control (Table 3). With the increase of Cd concentrations from 1 to $20 \mathrm{mg} / \mathrm{kg}$, the $\mathrm{Ci}$ of grape seedlings had the trend of decreasing.

Table 3 Effects of $\mathrm{Cd}$ stress on gas exchange parameters of grape seedlings

\begin{tabular}{|c|c|c|c|}
\hline Treatments & $\begin{array}{c}\mathrm{Ci} \\
\left(\mu \mathrm{mol} \cdot \mathrm{CO}_{2} / \mathrm{mol}\right)\end{array}$ & $\begin{array}{c}\text { Gs } \\
\left(\mathrm{mol} \mathrm{H} \mathrm{H}_{2} \mathrm{O} / \mathrm{m}^{2} \cdot \mathrm{s}\right)\end{array}$ & $\begin{array}{c}\text { VpdL } \\
(\mathrm{kPa})\end{array}$ \\
\hline Jufeng & & & $1.31 \pm 0.075 \mathrm{~b}$ \\
\hline 0 & $301 \pm 12.55 \mathrm{c}$ & $0.286 \pm 0.071 \mathrm{a}$ & $1.29 \pm 0.087 \mathrm{~b}$ \\
\hline 1 & $335 \pm 9.81 \mathrm{a}$ & $0.445 \pm 0.012 \mathrm{a}$ & $1.35 \pm 0.061 \mathrm{~b}$ \\
\hline 5 & $329 \pm 2.80 \mathrm{ab}$ & $0.384 \pm 0.092 \mathrm{a}$ & $1.60 \pm 0.078 \mathrm{a}$ \\
\hline 10 & $323 \pm 17.08 \mathrm{ab}$ & $0.383 \pm 0.106 \mathrm{a}$ & $1.51 \pm 0.081 \mathrm{a}$ \\
\hline 15 & $320 \pm 7.23 \mathrm{abc}$ & $0.322 \pm 0.158 \mathrm{a}$ & $1.48 \pm 0.064 \mathrm{a}$ \\
\hline 20 & $311 \pm 8.45 \mathrm{bc}$ & $0.304 \pm 0.063 \mathrm{a}$ & $1.05 \pm 0.071 \mathrm{~b}$ \\
\hline Xiahei & & & $1.02 \pm 0.062 \mathrm{~b}$ \\
\hline 0 & $291 \pm 9.35 \mathrm{~d}$ & $0.276 \pm 0.026 \mathrm{c}$ & $1.04 \pm 0.072 \mathrm{~b}$ \\
\hline 1 & $353 \pm 10.70 \mathrm{a}$ & $0.401 \pm 0.023 \mathrm{a}$ & $1.17 \pm 0.053 \mathrm{a}$ \\
\hline 5 & $341 \pm 11.97 \mathrm{ab}$ & $0.364 \pm 0.021 \mathrm{~b}$ & $1.11 \pm 0.071 \mathrm{ab}$ \\
\hline 10 & $327 \pm 6.30 \mathrm{bc}$ & $0.334 \pm 0.009 \mathrm{~b}$ & $1.07 \pm 0.034 \mathrm{ab}$ \\
\hline 15 & $320 \pm 7.92 \mathrm{c}$ & $0.331 \pm 0.021 \mathrm{~b}$ & \\
\hline 20 & $318 \pm 5.10 \mathrm{c}$ & $0.293 \pm 0.007 \mathrm{c}$ & \\
\hline
\end{tabular}

Stomatal Conductance (Gs). The same as the Tr, The Gs of grape seedlings increased under Cd stress compared with the control (Table 3). With the increase of $\mathrm{Cd}$ concentrations from 1 to 20 $\mathrm{mg} / \mathrm{kg}$, the Gs of grape seedlings had the trend of decreasing. Compared with the control, the Gs differences of 'Jufeng' seedlings under Cd treatments were not significant, but 'Xiahei' seedlings were significant. 
Vapor Pressure Deficit of Leaf (VpdL). With the increase of Cd concentrations, the Vpdl of grape seedlings had the trend of increasing when the dose of Cd was not more than $10 \mathrm{mg} / \mathrm{kg}$, and decreased when the dose of $\mathrm{Cd}$ was higher than $10 \mathrm{mg} / \mathrm{kg}$ (Table 3). The maxima of 'Jufeng' and 'Xiahei' seedlings were 1.60 and $1.17 \mathrm{kPa}$ respectively at $10 \mathrm{mg} / \mathrm{kg} \mathrm{Cd}$.

\section{Conclusions}

Under Cd stress, with the increase of $\mathrm{Cd}$ concentrations, the photosynthetic pigment content and net photosynthetic rate decreased. The transpiration rate, $\mathrm{CO}_{2}$ concentration of intercellular and stomatal conductance increased under $\mathrm{Cd}$ stress compared with the control, but water use efficiency decreased. With the increase of $\mathrm{Cd}$ concentrations, the vapor pressure deficit of leaf had the trend of increasing when the dose of Cd was not more than $10 \mathrm{mg} / \mathrm{kg}$, and decreased when the dose of Cd was higher than $10 \mathrm{mg} / \mathrm{kg}$.

\section{Acknowledgements}

This work was financially supported by the Application Infrastructure Project of Science and Technology Department of Sichuan Province (2016JY0258).

\section{References}

[1] X.L. Zhong, S.L. Zhou, M.L. Huang and Q.G. Zhao: Ecology and Environmental Sciences Vol 18 (2009), p. 1266.

[2] C.Y. Ma, D.J. Cai and H. Yan: Henan Chemical Industry Vol 30 (2013), p. 17.

[3] J.Y. Li: Environmental problems and Countermeasures of Intensive Agriculture (China Agriculture Press, Beijing, China 2001).

[4] J.G. Feng, X. Tao and S.A. Sheng: Chinese Agricultural Science Bulletion Vol 14 (1998), p. 29.

[5] J.T. Li, J.W. Qiu, X.W. Wang, Y. Zhou, C.Y. Lan and W.S. Shu: Environment Pollution Vol 143 (2006), p. 159.

[6] X.X. Wang and H. Deng: Sichuan Agriculture and Technology Vol 45 (2014), p. 28.

[7] C.T. Wang: Chinese Horticulture AbstractsVol 28 (2012), p. 159.

[8] L.Y. Zhang: Sino-Overseas Grapevine \& Wine Vol 38 (2015), p. 64.

[9] S.H. Li, L.J. Wang, P.G. Fan and M.R. Yang: Heibei Forestry Science and Technology Vol 32 (2004), p. 107.

[10]J. Li, L. Pu, Q. Liao,M. Zhu, X. Dai, Y. Xu, L. Zhang, M. Hua and Y. Jin: Environmental Earth Sciences Vol 73(20154), p.1823.

[11]M. Wang, B. Markert, W. Chen, C. Peng and Z. Ouyang: Environmental Monitoring and Assessment Vol 184 (2012), p. 5889.

[12]Z.B. Hao, J. Cang and Z. Xu: Plant Physiology Experiment (Harbin Institute of Technology Press, Harbin, China 2004).

[13]X.J. Jiang, H. Wang, W. Peng, Y.X. Yang, X.M. Zhu and L.J. Lin: Shanxi Journal of Agricultural Sciences Vol 54 (2008), p. 56. 